\title{
Evaluation of udder health parameters and risk factors for clinical mastitis in Dutch dairy herds in the context of a restricted antimicrobial usage policy
}

\author{
I. M. G. A. Santman-Berends, ${ }^{* 1}$ J. M. Swinkels, ${ }^{*}$ T. J. G. M. Lam, ${ }^{*} \dagger$ J. Keurentjes, ${ }^{*}$ and G. van Schaik ${ }^{*} \dagger$ \\ ${ }^{*}$ GD Animal Health, PO Box 9, 7400 AA Deventer, the Netherlands \\ †Department of Farm Animal Health, Faculty of Veterinary Medicine, Utrecht University, PO Box 80151, 3508 TD Utrecht, the Netherlands
}

\begin{abstract}
Recently, many changes have been implemented in Dutch dairy herds. Herd sizes have increased and antimicrobial use has been reduced. Certain types of antimicrobials can only be used in specific circumstances, and the preventive use of antimicrobials in dry cows is prohibited. The aim of this study was to quantify clinical mastitis (CM), subclinical mastitis (SCM), and risk factors associated with $\mathrm{CM}$ in Dutch dairy herds in 2013, in the context of these changes. For this study, 240 dairy herds were randomly selected from farms that participated in test-day milk recording, used a conventional milking system, and agreed to participate in the study. Eventually, 233 Dutch dairy farmers had complete records of CM in their herds in 2013 and 224 of these farmers completed a questionnaire on management factors potentially associated with CM. All participating farmers gave consent to use their routinely collected herd data such as test-day records and cow identification and registration data. Clinical and subclinical mastitis incidence rate (CMI and SCMI, respectively) per 100 cows per year, subclinical mastitis prevalence, and average bulk tank milk somatic cell count were obtained for 2013. The risk factor analysis was conducted using a generalized linear model with a $\log$ link function and a negative binomial distribution on herd level in Stata 13.1. A median CMI of 28.6 per 100 cows at risk per year, SCMI of 70.1 per 100 cows at risk per year, SCM prevalence of $15.8 \%$, and bulk tank milk somatic cell count of $171 \times 10^{3}$ cells $/ \mathrm{mL}$ were observed in 2013. Factors that were significantly associated with a higher CMI were cleaning slatted floors only once per day compared with more than 4 times a day (i.e., mechanical), a higher percentage of Holstein Friesian cows present in the herd, treating less than $50 \%$ of the cows with CM with antimicrobials, postmilking teat disinfection, and treatment of cows with elevated somatic cell count with antimicrobials.
\end{abstract}

Received September 14, 2015.

Accepted January 2, 2016.

${ }^{1}$ Corresponding author: i.santman@gdanimalhealth.com
The results of this study indicated that udder health had not deteriorated compared with udder health in previous Dutch studies where herd sizes were somewhat smaller and before the restrictions in antimicrobial use. Several of the risk factors that were found can be influenced by the farmer and can prevent the occurrence of CMI. Still, when cases of CM occur, treatment with antimicrobials might be necessary to cure the CM case and is beneficial for the overall udder health in the herd.

Key words: dairy cattle, clinical mastitis, risk factor, udder health

\section{INTRODUCTION}

Worldwide, mastitis is an important disease because of its common occurrence and its significant economic effect (Huijps et al., 2008; Olde Riekerink et al., 2008; Lam et al., 2013). In the Netherlands, the last representative estimate of $\mathrm{CM}$ was conducted as part of the national udder health program in 2009 (Lam et al., 2013). Nevertheless, since that study many changes have been implemented in Dutch dairy herds. Herd size has increased from an average of 82 cows ( $>2 \mathrm{yr}$ ) in 2009 to 90 cows ( $>2$ yr) in 2013, and antimicrobial use (AMU) was restricted by a new policy aiming to avoid the development of antimicrobial resistance (Hendriksen et al., 2008; Graveland et al., 2011; Scott and Menzies, 2011). For Dutch dairy herds, this meant that antimicrobials that were supplied to farmers by the veterinary practice had to be registered and monitored, restrictions on the use of second and third preference antimicrobials were put into place, and all prophylactic applications of antimicrobials such as blanket dry cow treatment were banned (KNMvD, 2013). As a result, the average animal defined daily dose of AMU per year (ADDD/yr) in the dairy industry decreased from 5.0 in 2010 (Hage and Van Deur, 2011) to 3.0 and 2.3 in 2013 and 2014, respectively (SDa, 2014, 2015). These developments may have had an effect on udder health in general and increased the need to optimize management to prevent mastitis and maintain good udder health. 
Table 1. Questionnaire topics potentially associated with clinical mastitis in the study herds

\begin{tabular}{ll}
\hline Topics & Description \\
\hline General & Herd size, pasturing in summer, replacement rate, growth in herd size in 2013, purchase of cattle in 2013 \\
Housing & Number of cubicles, bedding, type of floor, usage of antiseptics in the cubicles \\
Hygiene & Cleaning frequency of cubicles and slatted floors \\
Milking hygiene & Cleaning udder, management of the cows directly after milking, usage of milking gloves, pre- and postmilking teat \\
& disinfection, cleaning milk parlor (when, how, and frequency) \\
Mastitis & Farmers' definition of clinical mastitis, mastitis detection methods, antimicrobial treatment of subclinical and clinical \\
& mastitis, dry cow therapy, motivation for selective dry-cow treatment, usage of internal teat sealants \\
\hline
\end{tabular}

Many studies have investigated management factors associated with subclinical mastitis (SCM) (Breen et al., 2009a; Devries et al., 2012; Cicconi-Hogan et al., 2013; Gordon et al., 2013) or clinical mastitis (CM; Barkema et al., 1999; Barnouin et al., 2005; O'Reilly et al., 2006; Breen et al., 2009b; Jansen et al., 2009; Richert et al., 2013). These studies were performed, however, in a situation without restrictions on AMU. A study of Passchyn et al. (2014) showed that risk factors for intramammary infections differed between treated and untreated heifers.

Whether the changes in the Dutch dairy industry such as increasing herd size and AMU restriction had an effect on udder health and whether it changed the risk factors for CM was unknown. Therefore, the aim of this study was to estimate udder health parameters and to identify risk factors associated with CM incidence rate (CMI) in Dutch dairy herds in 2013, in the context of these changes.

\section{MATERIALS AND METHODS}

\section{Study Population}

Based on sample size calculations, at least 200 dairy herds had to be included to be able to estimate the CMI with a maximum accepted error of 5 to $6 \%$, and to detect risk factors with an incidence rate ratio of 2.5 or higher (assuming 95\% confidence, 80\% power, and an expected CMI of 25-30). The drop-out percentage was expected to be at most $20 \%$. Therefore, it was decided to include 240 dairy herds in this study. The inclusion criteria for enrollment into the study were farms with a conventional milking parlor and routine 4 to 6 weekly test-day milk recording to ensure a uniform detection method of CM and similar routine herd data among the study herds. A total of 1,350 dairy herds that met the inclusion criteria were randomly selected using Stata version 13.1 (StataCorp, 2014) and were requested to participate in the study by mail. The first 240 farmers that responded were included.

\section{Data Collection}

All enrolled herds were visited during the first month of the study by an employee of GD Animal Health who was specialized in udder health management. At each of these visits, the aim of the study and the definition of CM were explained and farmers were asked to use standard forms to register CM. Farmers were asked to register all CM cases from January 1 to December 31, 2013. During the farm visit, the farmer completed a questionnaire on daily management practices (Table 1). This questionnaire included questions on factors that were assumed to be associated with the occurrence of $\mathrm{CM}$ and potentially gave the farmer the possibility to improve and reduce CM. The answers of the questionnaire were digitalized using NetQ premium (NetQuestionnaires Nederland BV, 2014). Finally, all participating farmers gave consent for usage of their routinely collected herd data.

To ensure high data quality and reduce bias, farmers were reminded by e-mail and telephone to return the forms at the end of each month. A procedure was developed in Stata 13.1 (StataCorp, 2014) to be able to timely detect incomplete records and administrative errors. When abnormalities were detected, the farmer was contacted immediately and the submitted data were corrected. For analytical purposes, herd level CM data were combined with the results of the questionnaire and routine test-day milk recording data [provided by the Dutch Royal Cattle Syndicate (CRV, Arnhem)], cow identification and registration data $[\mathrm{I} \& \mathrm{R}$, provided by the Dutch Enterprise Agency (RVO, Den Haag)], and bulk milk SCC (BMSCC) data at a 2-wk interval (provided by Qlip Laboratories, Zutphen). Finally, records on antimicrobial supplies (originating from the MediRund database) were provided by the Dutch Commodity board for dairy (PZ, the Hague). From these data, the ADDD/yr was calculated for intramammary treatment (antimicrobials applied for CM and dry cow treatment) according to the method described by Santman-Berends et al. (2015). 


\section{Definitions}

For each of the herds, udder health parameters that were evaluated were CMI per 100 cows per year, subclinical mastitis incidence rate (SCMI) per 100 cows at risk per year, average subclinical mastitis prevalence in 2013 (SCMP), and average BMSCC in 2013.

Clinical Mastitis Incidence Rate. The CMI was calculated as the number of CM cases divided by the number of cow days at risk (DAR), multiplied by $365 \mathrm{~d}$ and 100 cows. In this study, CM was defined as every abnormality of udder, milk, or both according to the definition described in Lago et al. (2011). Abnormalities in milk included abnormal color, viscosity, or consistency, with or without accompanying heat, pain, redness, or swelling of the quarter, or generalized illness. The CM cases occurring in the same quarter within $14 \mathrm{~d}$ after the previous case were considered to be the same case (Jansen et al., 2009; van den Borne et al., 2010; Lam et al., 2013). Days at risk were calculated as the total sum of the number of days each cow was present in the herd during the study period. Cows were assumed to be always at risk for $\mathrm{CM}$ because even if they suffered from CM in a quarter, they were still at risk for developing $\mathrm{CM}$ in one of the other quarters.

Subclinical Mastitis Incidence Rate. The SCMI was calculated per 100 cows at risk per year as the number of new SCM cases divided by DAR, multiplied by $365 \mathrm{~d}$ and 100 cows. Diagnosis of SCM was based on individual SCC results at test-day level and was defined as having an elevated SCC, $>150 \times 10^{3}$ cells/ $\mathrm{mL}$ for primiparous and $\mathrm{SCC}>250 \times 10^{3}$ cells $/ \mathrm{mL}$ for multiparous cows (CRV, 2010; Lam et al., 2013). A new case of SCM was defined as either a cow with an elevated SCC on the first test-day milk recording after calving, representing either a dry period or an early lactation originated infection, or a cow with a new elevated SCC at the second to later test-day measurement. A new elevated SCC at the second to later test-day measurement was defined as an elevated SCC after 1 or 2 earlier low SCC measurements $(\leq 150 \times$ $10^{3}$ cells $/ \mathrm{mL}$ primiparae and $\leq 250 \times 10^{3}$ cells $/ \mathrm{mL}$ multiparae). Test-day results obtained within the first $4 \mathrm{~d}$ after calving were excluded from the analyses because an elevated SCC in the first days of lactation is likely due to a physiological effect (Dohoo, 1993; Barkema et al., 1999). The DAR for developing a new case of SCM was calculated for each cow as the number of lactating days the cow was at risk for developing an elevated SCC in 2013. During the dry period, the time before first calving, the first $4 \mathrm{~d}$ after calving, and the time between successive recordings while the cow is defined as infected as measured by SCC, the cow was not at risk for SCM and these days were not included in the DAR. From d 5 in lactation, the cow was assumed to be at risk for developing SCM. The cow remained at risk until the test-day milk recording on which an elevated SCC was detected. The DAR on cow-level were summed for each of the participating herds to obtain DAR at herd level in 2013.

Average Subclinical Mastitis Prevalence. The SCMP was calculated per herd as the average percentage of cows with elevated SCC in each of the test-day observations in 2013. The percentage of cows with an elevated SCC per test-day measure was calculated by dividing the total number of elevated SCC cows by the total number of cows participating in the test-day milk recording.

Average Bulk Tank Milk SCC. For each of the participating herds, bimonthly BMSCC results were available and the average BMSCC was calculated as the mean of all individual BMSCC results in 2013.

\section{Statistical Analyses}

Results of the udder health parameters were presented using descriptive statistics in Stata 13.1 (StataCorp, 2014). For the risk factor analyses, a generalized linear model with a log link function and a negative binomial distribution model on herd level was used with the number of $\mathrm{CM}$ cases as dependent variable and DAR as exposure. The variables derived from the questionnaire were subjected to univariable analyses. Variables with $P \leq 0.3$ (Z-test) were retained for inclusion in the multivariable model. The multivariable analysis was done using a backward stepwise selection and elimination procedure. After each run, the variable with the highest $P$-value was excluded from the model until all variables had $P \leq 0.05$. The most optimal model was evaluated using the Akaike information criterion (AIC), where an AIC closest to zero was deemed the best model (Akaike, 1974). Confounding was monitored by the change in the coefficient of a variable after removing another variable from the model. If the change of the estimates exceeded $25 \%$ or 0.1 when the value of the estimate was between -0.4 and 0.4 , the removed variable was considered a potential confounder and was re-entered in the model. The robustness of the final model was checked by carrying out the same procedure with forward stepwise selection and elimination. In the final model, all biological credible 2-way interactions were tested. Model fit was evaluated by checking normality of the residuals. 


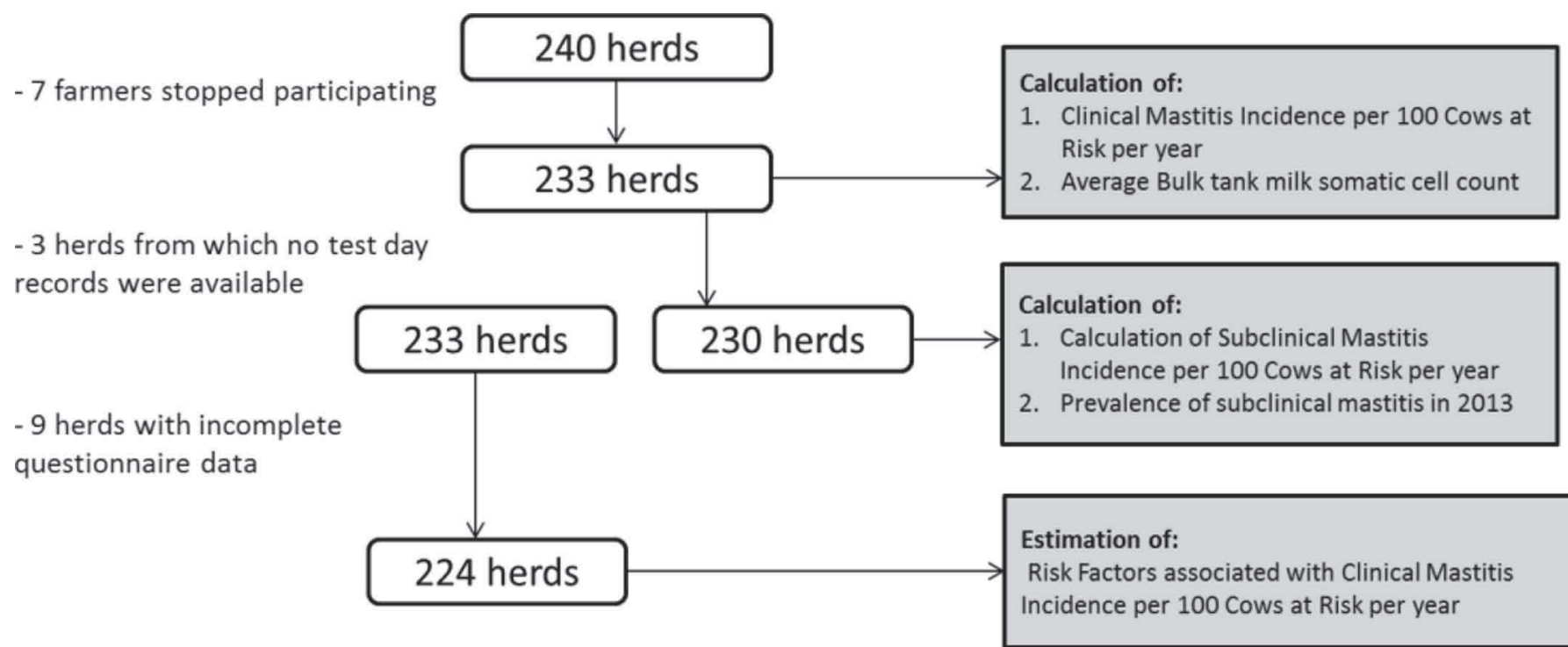

Figure 1. Schematic overview of the 240 initially enrolled herds and the number of herds included for calculating of the udder health parameters and evaluation of risk factors for clinical mastitis in 2013.

\section{RESULTS}

\section{Descriptive Statistics of Participating Herds}

From the 240 dairy farmers that initially started to participate in the study, 233 completed data collection. Seven farmers dropped out during the year because the administrative work was perceived to be too laborious $(\mathrm{n}=4)$ or because of personal circumstances $(\mathrm{n}=3)$. In the 233 herds, a total of 6,760 quarter-level CM cases in 4,947 different cows were registered in 2013. In most cows with CM, only one quarter was affected ( $95 \%$ of the cases). In $4 \%$ of the cases, 2 quarters were affected and in $0.3 \%$ and $0.4 \%$, respectively, 3 and 4 quarters with $\mathrm{CM}$ were observed. The participating dairy herds [104 cows (>2 yr)] appeared slightly larger than the average Dutch herd (94 cows, census data). The geographical distribution of the study herds did not differ from the geographic distribution of all Dutch dairy herds.

In the participating herds, the average ADDD/yr (i.e., the number of antimicrobial treatments per cow during 2013) was 0.71 for mastitis treatment and 1.46 for dry cow therapy compared with an average of, respectively, 0.8 and 1.8 in all Dutch dairy herds (SDa, 2014). This meant that, in a herd with 100 milking cows, each cow needed on average $0.71 \mathrm{~d}$ of antimicrobials treatments for the treatment of one case of CM. Additionally, on average 1.46 treatments with antimicrobials for dry cow therapy were used. Given the yearly replacement rates in the Netherlands and the median percentage of $66 \%$ of the Dutch milking cows that are dried off per year (census data), an average ADDD/yr of 2.4 for dry cow therapy would be expected, when blanket dry cow therapy would be applied (using antimicrobials at drying off in one cow results in ADDD of 4). It appeared that in the study herds, only $61 \%(1.46 / 2.4)$ of the milking cows that were dried off were treated with antimicrobials in 2013.

\section{Udder Health Parameters}

Data of all 233 herds were included to calculate CMI and BMSCC. For calculating SCMI and SCMP, data of 3 herds were excluded because no test-day records were available, and the number of SCM cases and days at risk for calculating SCMI were not available (Figure 1).

The median CMI was 28.6 and the mean CMI was 32.2 per 100 cows per year in the 233 participating herds in 2013. The CMI ranged from 2 to 120 with an interquartile range of 20 to 41 . Data on SCMI were normally distributed with a median of 70.1 and a mean of 71.2 (interquartile range: 54-86) per 100 cows at risk per year. The SCMI varied between 8 and 166 .

The mean SCMP in the participating herds was $17.0 \%$ and varied from $1.3 \%$ to $56.6 \%$. The median SCMP was $15.8 \%$ and the interquartile rage varied between 12.2 and $21.1 \%$. Finally, BMSCC varied between a minimum of $35 \times 10^{3}$ and a maximum of $359 \times 10^{3}$ cells $/ \mathrm{mL}$ in the participating herds in 2013. The median BMSCC was $171 \times 10^{3}$ cells $/ \mathrm{mL}$ and the mean was 182 $\times 10^{3}$ cells $/ \mathrm{mL}$ (interquartile range: $146 \times 10^{3}$ to $221 \times$ $10^{3}$ cells $/ \mathrm{mL}$ ) and was lower than the average BMSCC 
Table 2. Descriptive results of risk factors univariable associated $(P<0.30)$ with clinical mastitis incidence rate $(\mathrm{CMI})$ per 100 cows per year in 224 Dutch dairy herds in 2013

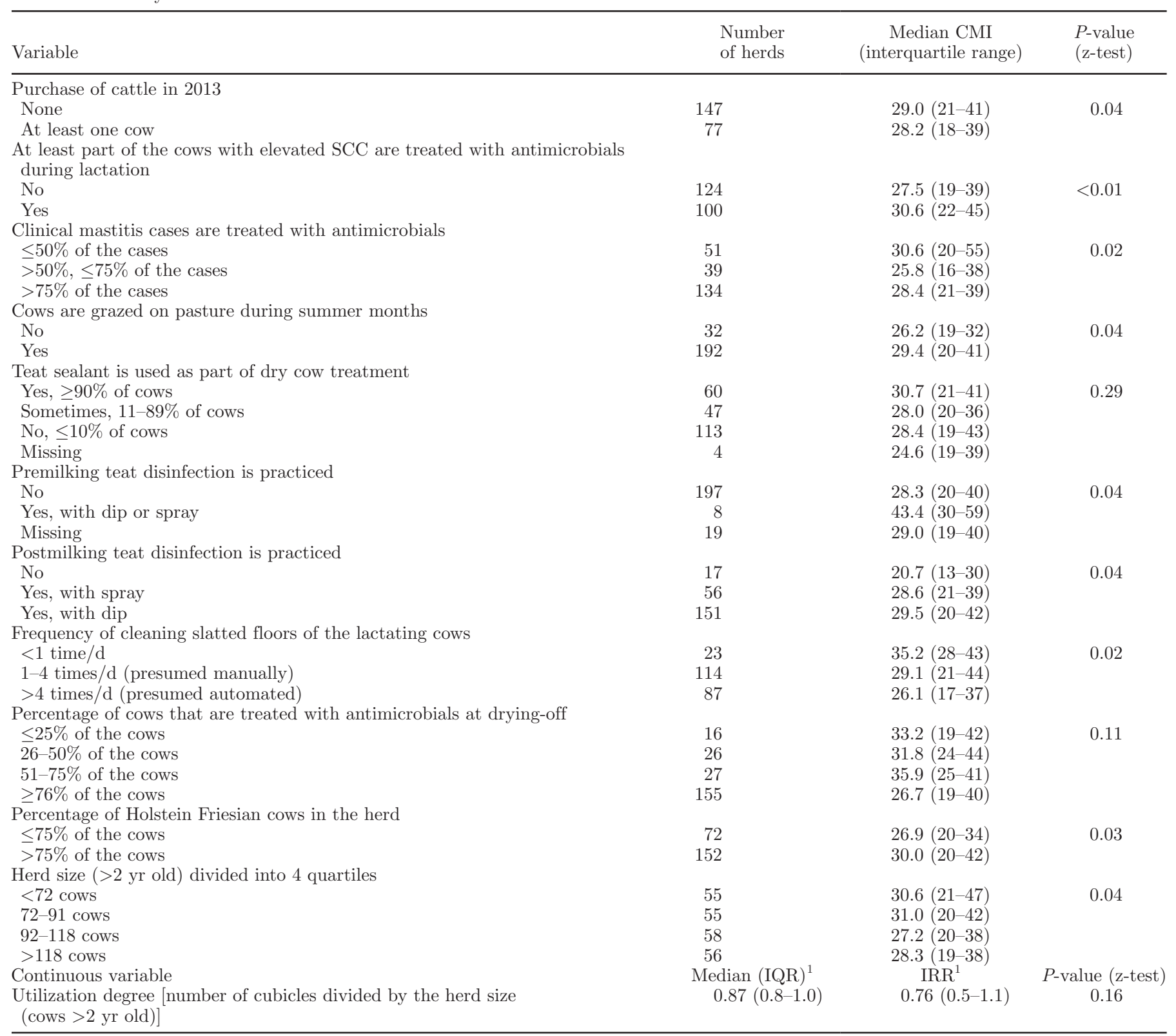

${ }^{1} \mathrm{IQR}=$ interquartile range; $\mathrm{IRR}=$ incidence rate ratio.

in the Netherlands during the same period $\left(199 \times 10^{3}\right.$ cells/mL, census data).

\section{Risk Factors Associated with CMI}

Of the participating herds, 224 of the 233 completed the questionnaire and were included in the risk factor analyses, evaluating 21 variables potentially associated with CMI. Thirteen variables were potentially associated with CMI $(P<0.30)$ in the univariable analyses and were included in the full multivariable model (Table
2 ). Correlations between the variables that entered the multivariable model were low $(\mathrm{r}>0.3)$.

The final model contained 5 variables that were significantly $(P<0.05)$ associated with CMI. The final model (AIC value closest to 0) explained 2\% (pseudo $\mathrm{R}^{2}$ ) of the variation in CMI. The residuals of the final model were normally distributed. The backward selection and elimination method and the forward selection and elimination method resulted in the same final model. Cleaning slatted floors more than 4 times per day was associated with a lower CMI compared with 
Table 3. Results of the multivariable regression model evaluating risk factors associated with clinical mastitis incidence rate in 224 Dutch dairy herds in 2013

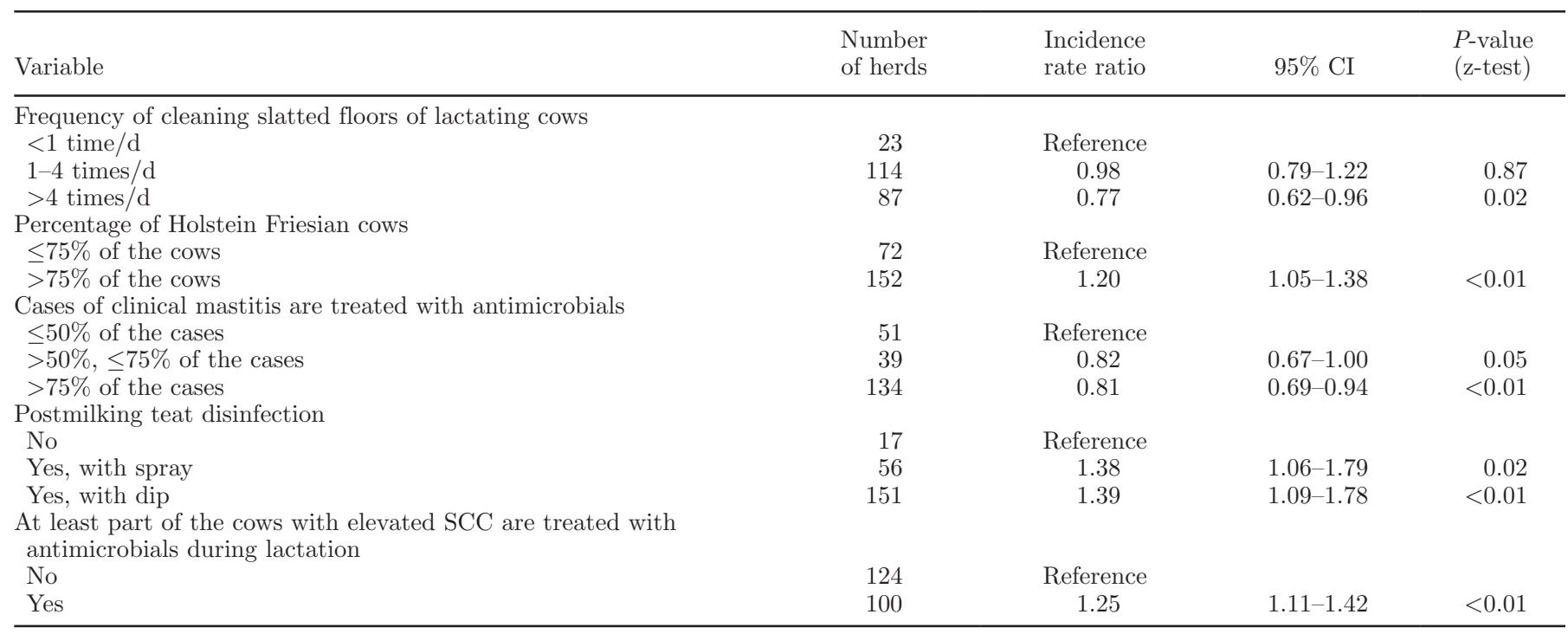

cleaning the slatted floors less than once every day. A higher percentage of Holstein Friesian (HF) cows, postmilking teat disinfection and treatment of elevated SCC cows with antimicrobials was associated with a higher CMI (Table 3). Treatment of more than half of the CM cases with antimicrobials was associated with a lower CMI compared with treatment of less than $50 \%$ of the CM cases (Table 3). The final model did not have confounding or multi-collinearity. In addition, none of the 2-way interactions were significantly associated with CMI, and these were therefore not included in the final model.

\section{DISCUSSION}

The aim of this study was to quantify udder health and risk factors associated with CMI in 2013. In that year, AMU was restricted in the Netherlands, but other factors also changed, such as an increasing herd size, possibly anticipating on the disappearance of the milk quota system in the forthcoming years The results showed a median CMI of 28.6 (mean 32.2) cases per 100 cows at risk per year and the final model showed 5 herd level variables that were associated with CMI. Although the variation in CMI that was explained by this model was low, the risk factors were in line with those that were described earlier (Elbers et al., 1998; Barkema et al., 1999; van den Borne et al., 2010). Our findings were in contrast with Passchyn et al. (2014), who found that risk factors for mastitis differed between heifers that were either treated or not treated with antimicrobials. However, the study of Passchyn et al. (2014) was not comparable to ours because of the differences in study design (clinical trial versus field study), the level of aggregation (quarter versus herd level) and because Passchyn et al. (2014), only included heifers whereas this study involved both primiparous and multiparous cows.

Our study showed that frequently cleaning of slatted floors in the lactating cow facilities ( $>4$ times per day), was associated with a lower CMI. These herds were assumed to have automated scrapers, which result in cleaner floors, cleaner claws, and thus less fecal contamination of the cubicles, which subsequently result in cleaner udders as has been described before (Barkema et al., 1999). A higher proportion of HF cows in the herd was associated with a higher CMI. From the literature, it is known that in general, HF cows have a higher milk yield compared with other breeds (Walsh et al., 2007; Prendiville et al., 2010; Vance et al., 2012; Piccand et al., 2013). Cows with a higher milk production may be less resilient and therefore more susceptible to CM. However, milking almost exclusively HF cattle might also be an indicator for other management practices associated with CM that were not included in the study. Treatment of more than half of the CM cases with antimicrobials was associated with a lower CMI compared with treatment of less than $50 \%$ of the cases. We have to realize, however, that diagnosis of $\mathrm{CM}$ is subjective and differences in diagnosis between dairy farmers have been described before (Lam et al., 1993). Cases of CM that are not treated properly may lead to chronic intramammary infections that are clinically cured but remain bacteriologically infected, resulting in a higher risk of recurrence (van den Borne et al., 2010; Swinkels et al., 2014). In our study, during the initial 
farm visit, we tried to standardize the diagnosis of $\mathrm{CM}$ and prevent differences in diagnosis between farmers as much as possible by explaining and discussing diagnostic methods and definitions of CM.

In our model, both treated and nontreated cases of $\mathrm{CM}$ were included as dependent variables. Farmers were asked to register whether antimicrobials were used in all cases of CM. From our data it appeared that farmers treated on average $72 \%$ of the registered $\mathrm{CM}$ cases with antimicrobials. Whether decisions to treat $\mathrm{CM}$ were based on culture results or merely clinical signs is unknown, although in the Dutch situation, it is more likely that the decision to treat a $\mathrm{CM}$ case is based on the severity of clinical signs. We evaluated whether the risk factors that were associated with CMI would change if we exclusively included treated CM cases as a dependent variable in our model. That model, however, remained unchanged, with the exception of one additional factor that entered the model, which was the frequency of cleaning the cubicles. Cleaning the cubicles once a day as compared with cleaning 2 to 4 times/d was associated with a higher incidence of CM cases that were treated with antimicrobials.

Applying postmilking teat disinfection was associated with higher CMI compared with no postmilking teat disinfection. This finding has been described in earlier studies (Schukken et al., 1990; Elbers et al., 1998; Barkema et al., 1999; Peeler et al., 2000) in which postmilking teat disinfection were described as risk factor. It might be that application of postmilking teat disinfection resulted in decreased infections with minor pathogens leading to an increased risk of infection with major pathogens (Lam et al., 1997a,b). This may partly explain this effect. Another explanation may be due to the fact that herds with a high CMI are more likely to take additional measures such as postmilking teat disinfection to try to reduce the CMI. Finally, we found that herds that never treated elevated SCC cows with antimicrobials had a lower CMI compared with herds in which part of the elevated SCC cows were treated. Elevated SCC is an important indicator for the development of CM (van den Borne et al., 2011). Therefore, it is possible that farmers with an elevated CMI in their cows decided to treat part of the cows with an elevated SCC during lactation to lower infection pressure and to prevent development of clinical signs. Additionally, it may be that treating SCM results in removal of minor pathogens leading to increased risk of infection with opportunistic pathogens (Sérieys et al., 2005). Nevertheless, it is also possible that farmers treating SCM with antimicrobials are also more dedicated on finding and treating CM cases, trying to be a good farmer (Swinkels et al., 2015).
We decided not to include AMU as independent variable in our models because we wanted to detect management practices that can be adapted to reduce the CMI. Nevertheless, data were available on the amount of delivered antimicrobials for intramammary use and for dry cow treatment during the study period, which is a proxy for AMU (Santman-Berends et al., 2015). When we included parameters on AMU in our model, a higher amount of usage of antimicrobials for intramammary treatment was associated with a significantly higher CMI. A higher AMU for drying off cows was associated with a significant lower CMI at the herd level, as was earlier described by Scherpenzeel et al. (2014). Our study was not comparable to the study of Scherpenzeel et al. (2014) because they evaluated dry cow treatment as such, ignoring the potential preventive effect of internal teat sealants (Bradley et al., 2010). In our study, the use of internal teat sealants was evaluated, although no significant effect of teat sealants was observed in the final model.

The CMI (mean 32.2, median 28.6) found in this study was higher compared with the last CMI measure in 2009 (mean 28.1, Lam et al., 2013). This could indicate that the restricted AMU including the limited possibilities to use antimicrobials at drying off resulted in higher CMI. This increase might also be associated with the increase in herd size from an average of 82 cows (>2 yr) in 2009 to 90 cows (>2 yr) in 2013 (based on census data, data not shown). Increase in herd size led to reduced replacement percentages and thus less cattle being removed from the herd because of, among others, udder health issues. Finally, the difference in CMI that was found may also be associated with a very strict protocol for data collection in the participating herds. In this study, recall bias was prevented as much as possible by sending monthly reminders to the farmers to submit recorded cases of $\mathrm{CM}$, whereas in the previous study, farmers were reminded less frequently. This might have resulted in a slight underestimation of the CMI in 2009. This latter hypothesis was supported by the fact that the SCMP that was found in this study, which is a more objective parameter, was lower (median 15.8\%; mean 17.1\%) than the SCMP found in 2009 (mean 22.2\%), before restrictions on AMU were in place (Lam et al., 2013). Furthermore, a national udder health program (Lam et al., 2013) has increased awareness about CM, and farmers may have adopted a stricter routine for detection of CM cases. It seems fair to conclude that the CMI found in our study was in the same range as previous Dutch studies. In Great Britain and Denmark, the CMI seems slightly higher than in the Netherlands, with averages of 36 and 48 cases per 100 cows per year, respectively (Bartlett et 
al., 2001; O'Reilly et al., 2006; Bradley et al., 2007; Sato et al., 2008). In Canada and Switzerland, the observed CMI was lower than the CMI found in our study with averages of 14.721 .3 cases per 100 cows per year, respectively (Gordon et al., 2013; Elghafghuf et al., 2014). The CMI in these studies may differ because of differences in herd size, milk production, $\mathrm{AMU}$, and enrolment criteria for participation in the different studies. Nevertheless, whether there were any restrictions on AMU in previous studies, and whether $\mathrm{AMU}$ in other countries was comparable to AMU in the Netherlands, was unknown. The average BMSCC (182 $\times 10^{3}$ cells $/ \mathrm{mL}$ ) in our study appeared to be lower than in other studies, where it ranged from $206 \times 10^{3}$ to 470 $\times 10^{3}$ cells $/ \mathrm{mL}$ (Lukas et al., 2005; Norman et al., 2010; Gillespie et al., 2012; Olde Riekerink et al., 2012).

When we compared our results to the average Dutch dairy herd, both the SCM prevalence and the BMSCC were slightly lower in the study herds (17\% versus $18 \%$, respectively, and $182 \times 10^{3}$ cells $/ \mathrm{mL}$ versus $199 \times 10^{3}$ cells $/ \mathrm{mL}$, respectively, in the study and average Dutch dairy herd). This indicated that the participating herds were performing slightly better with regard to udder health compared with the Dutch average. Thus, the study herds may not be completely representative for the Dutch population. For this study, a random group of dairy herds was selected from all herds that milked with a conventional milking parlor and participated in the milk recording system. Nevertheless, the farmers that responded to our request might have had a more than average interest in udder health. This might have led to some selection bias. However, voluntary participation is the only way to obtain a reliable estimate of CM because the participating farmers had to be dedicated to finish a whole year of observing $\mathrm{CM}$ in their cows.

The questionnaire was conducted within a 1-mo period during the first visit to exclude seasonal influences. Subsequently, CMI was monitored during the rest of the year and linked to the answers of the questionnaire. We believe that the fact that the questionnaire was conducted during the start of the study, whereas the CMI was measured thereafter, did not have a large effect on the study outcomes because we did not provide any advice with regard to udder health management during the study period. In addition, the farmers did not receive any information on preliminary outcomes that could have influenced them. For validation purposes, we compared the percentage of treated CM cases registered by the famer during 2013, with the farmers' answer on the percentage of $\mathrm{CM}$ cases treated with antimicrobials. The percentage of treated CM cases indicated by the farmer at the beginning of the study appeared to be a good prediction of the actual registered percentage of CM cases during 2013 (correlation $\mathrm{r}=$ 0.6). The actual percentage of treated CM cases based on registrations during 2013 probably gave a slightly better indication of treatment of CM compared with the answer of the questionnaire. However, our conclusions did not change when we included the registered percentage of treated $\mathrm{CM}$ cases in the model instead of the indicated percentage (data not shown). We decided to keep the indicated percentage of treated CM recorded by the farmer.

From this study, it could not be concluded that the restricted AMU resulted in decreased udder health in Dutch dairy herds. Although with this type of study no causality is proven, the risk factors for CM were biologically plausible and were not different as compared with the period before 2013, the year of the AMU restrictions. When restricted AMU is combined with sufficient preventive management measures, it seems that the CMI can remain at the same level. In our study, we did not have any have any information regarding AMU of the studied herds before the study period. Nevertheless, we do know that AMU in the studied herds was in the same range of the average Dutch dairy herd, that the possibilities to use antimicrobials were significantly decreased due to the change in policy and that the proportion of cows that received DCT during the study year was quite low (61\%). Thus, although we cannot prove this, we concluded that the AMU in our study herds in 2013 would be lower compared with previous years. Other factors that were not included in the model might have led to a change in udder health between 2009 (Lam et al., 2013) and 2013, such as yearto-year variation in temperature, milk, and meat prices, and increased herd size. Nevertheless, the year 2013 was quite average with regard to the temperature and we know from our bi-annual analyses on udder health parameters in all Dutch dairy herds that the effect of milk and meat price on udder health in the Netherlands is negligible (data not shown). The increased herd size was assumed not to have led to a too optimistic view on udder health in our study because increasing herd sizes are assumed to have a detrimental effect on udder health. Following that, there were, to our knowledge, no additional changes other than restrictions on AMU that might have led to a change in udder health of Dutch dairy cattle. Thus, although we did not include a control group with which we could prove that the restriction in AMU truly did not result in decreased udder health, we believe from this study that it is possible to remain high udder health standards in a herd when the possibilities for AMU are restricted. Nevertheless, from our study, it seems important to treat CM cases with antimicrobials, which is beneficial for the overall udder health in a herd. 


\section{CONCLUSIONS}

This study determined the udder health status and risk factors for CMI in Dutch dairy herds in 2013. The evaluated udder health parameters such as CMI, SCMI, SCMP, and BMSCC appeared not to have changed and was comparable to previous studies in the period with smaller herd sizes and before the restricted AMU policy was in place. Cleaning slatted floors less than one time per day, a higher percentage of HF cows, postmilking teat disinfection, treatment of cows with an elevated SCC with antimicrobials, and treatment of less than half of the CM cases with antimicrobials were associated with a higher CMI. This indicates that management measures can reduce CMI. Nevertheless, this study indicated that when cases of $\mathrm{CM}$ occur, treatment with antimicrobials is necessary to cure CM and seems beneficial to the overall udder health in the herd.

\section{ACKNOWLEDGMENTS}

This study was financed by the Dutch Dairy Association (NZO) and the Dutch Commodity board for Dairy (PZ). We thank the 240 farmers for their participation and their commitment to this study. Furthermore, we thank the data suppliers (RVO, CRV, Qlip Laboratories) for providing herd data.

\section{REFERENCES}

Akaike, H. 1974. A new look at the statistical model identification. IEEE Trans. Automat. Contr. 19:716-723.

Barkema, H. W., Y. H. Schukken, T. J. G. M. Lam, M. L. Beiboer, G. Benedictus, and A. Brand. 1999. Management practices associated with the incidence rate of clinical mastitis. J. Dairy Sci. $82: 1643-1654$

Barnouin, J., S. Bord, S. Bazin, and M. Chassagne. 2005. Dairy management practices associated with incidence rate of clinical mastitis in low somatic cell score herds in France. J. Dairy Sci. 88:3700-3709.

Bartlett, P. C., J. F. Agger, H. Houe, and L. G. Lawson. 2001. Incidence of clinical mastitis in Danish dairy cattle and screening for non-reporting in a passively collected national surveillance system. Prev. Vet. Med. 48:73-83.

Bradley, A. J., J. E. Breen, B. Payne, P. Williams, and M. J. Green. 2010. The use of a cephalonium containing containing dry cow therapy and an internal teat sealant, both alone and in combination. J. Dairy Sci. 93:1566-1577.

Bradley, A. J., K. A. Leach, J. E. Breen, and M. J. Green. 2007. Survey of the incidence and aetiology of mastitis on dairy farms in England and Wales. Vet. Rec. 160:253-257.

Breen, J. E., A. J. Bradley, and M. J. Green. 2009a. Quarter and cow risk factors associated with a somatic cell count greater than 199,000 cells per milliliter in United Kingdom dairy cows. J. Dairy Sci. 92:3106-3115.

Breen, J. E., M. J. Green, and A. J. Bradley. 2009b. Quarter and cow risk factors associated with the occurrence of clinical mastitis in dairy cows in the United Kingdom. J. Dairy Sci. 92:2551-2561.

Cicconi-Hogan, K. M., M. Gamroth, R. Richert, P. L. Ruegg, K. E. Stiglbauer, and Y. H. Schukken. 2013. Associations of risk factors with somatic cell count in bulk tank milk on organic and conventional dairy farms in the United States. J. Dairy Sci. 96:3689-3702.
CRV (Dutch Royal Cattle Syndicate). 2010. Definitions of somatic cell count. Accessed Dec. 25, 2014. https://www.crv4all.nl/downloads/ fokkerij/naslagwerken.

Devries, T. J., M. G. Aarnoudse, H. W. Barkema, K. E. Leslie, and M. A. Von Keyserlink. 2012. Associations of dairy cow behavior, barn hygiene, cow hygiene, and risk of elevated somatic cell count. J. Dairy Sci. 95:5730-5739.

Dohoo, I. R. 1993. An evaluation of the validity of individual cow somatic cell counts from cows in early lactation. Prev. Vet. Med. 16:103-110.

Elbers, A. R. W., J. D. Miltenburg, D. De Lange, A. P. P. Crauwels, H. W. Barkema, and Y. H. Schukken. 1998. Risk factors for clinical mastitis in a random sample of dairy herds from the southern part of The Netherlands. J. Dairy Sci. 81:420-426.

Elghafghuf, A., S. Dufour, K. Reyher, I. Dohoo, and H. Stryhn. 2014. Survival analysis of clinical mastitis data using a nested frailty Cox model fit as a mixed-effects Poisson model. Prev. Vet. Med. 117:456-468.

Gillespie, B. E., M. J. Lewis, S. Boonyayatra, M. L. Maxwell, A. Saxton, S. P. Oliver, and R. A. Almeida. 2012. Short communication: Evaluation of bulk tank milk microbiological quality of nine dairy farms in Tennessee. J. Dairy Sci. 95:4275-4284.

Gordon, P. F., B. H. Van Den Borne, M. Reist, S. Kohler, and M. G. Doherr. 2013. Questionnaire-based study to assess the association between management practices and mastitis within tie-stall and free-stall dairy housing systems in Switzerland. BMC Vet. Res. http://dx.doi.org/10.1186/1746-6148-9-200.

Graveland, H., B. Duim, E. Van Dijkeren, D. Heedrik, and J. A. Wagenaar. 2011. Livestock-associated methicillin-resistant Staphylococcus aureus in animals and humans. Int. J. Med. Microbiol. 301:630-634.

Hage, H., and I. Van Deur. 2011. Monitoring antimicrobial use in cattle herds in 2010 (in Dutch). GD Animal Health, Deventer, the Netherlands.

Hendriksen, R. S., D. J. Mevius, A. Schroeter, C. Teale, D. Meunier, P. Butaye, A. Franco, A. Utinane, A. Amado, M. Moreno, C. Greko, K. Stärk, C. Berghold, A. L. Myllyniemi, D. Wasyl, M. Sunde, and F. M. Aarestrup. 2008. Prevalence of antimicrobial resistance among bacterial pathogens isolated from cattle in different European countries: 2002-2004. Acta Vet. Scand. 50:28 http://dx.doi org/10.1186/1751-0147-50-28.

Huijps, K., T. J. Lam, and H. Hogeveen. 2008. Costs of mastitis: Facts and perception. J. Dairy Res. 75:113-120.

Jansen, J., B. H. Van Den Borne, R. J. Renes, G. Van Schaik, T. J. Lam, and C. Leeuwis. 2009. Explaining mastitis incidence in Dutch dairy farming: The influence of farmers' attitudes and behaviour. Prev. Vet. Med. 92:210-223.

KNMvD. 2013. Directive of the use of antimicrobials for dry cow therapy in dairy cows (in Dutch). Accessed Sep. 14, 2015. https://www. knmvd.nl/dossiers/12108456/Antibiotica/actueel/item/10833979/ KNMvD-publiceert-eerste-richtlijnen-voor-dierenartsen-oververantwoord-antibioticumgebruik.

Lago, A., S. M. Godden, R. Bey, P. L. Ruegg, and K. Leslie. 2011. The selective treatment of clinical mastitis based on on-farm culture results: I. Effects on antibiotic use, milk withholding time, and short-term clinical and bacteriological outcomes. J. Dairy Sci 94:4441-4456.

Lam, T. J. G. M., Y. H. Schukken, F. J. Grommers, J. A. H. Smit, and A. Brand. 1993. Within-herd and between-herd variation in diagnosis of clinical mastitis in cattle. JAVMA 202:938-942.

Lam, T. J. G. M., B. H. P. Van Den Borne, J. Jansen, K. Huijps, J. C. L. Van Veersen, G. Van Schaik, and H. Hogeveen. 2013. Improving bovine udder health: A national control program in the Netherlands. J. Dairy Sci. 96:1301-1311.

Lam, T. J. G. M., J. H. van Vliet, Y. H. Schukken, F. J. Grommers, A. Van Velden-Russcher, H. W. Barkema, and A. Brand. 1997a. The effect of discontinuation of postmilking teat disinfection in low somatic cell count herds. I. Incidence of clinical mastitis. Vet. Q. 19:41-47.

Lam, T. J. G. M., J. H. van Vliet, Y. H. Schukken, F. J. Grommers, A. Van Velden-Russcher, H. W. Barkema, and A. Brand. 1997b. 
The effect of discontinuation of postmilking teat disinfection in low somatic cell count herds. II. Dynamics of intramammary infections. Vet. Q. 19:47-53.

Lukas, J. M., D. M. Hawkins, M. L. Kinsel, and J. K. Reneau. 2005. Bulk tank somatic cell counts analyzed by statistical process control tools to identify and monitor subclinical mastitis incidence. J. Dairy Sci. 88:3944-3952.

MARAN-2012. 2013. Monitoring of Antimicrobial Resistance and Antibiotic Usage in Animals in the Netherlands in 2012. Accessed Feb. 25, 2015. http://www.wageningenur.nl/nl/ExpertisesDienstverlening/Onderzoeksinstituten/Central-VeterinaryInstitute/Publicaties-CVI/MARAN-Rapporten.htm.

NetQuestionnaires Nederland BV. 2014. Manual NETQ Internet Surveys 6.0. NetQuestionnaires Nederland BV, Utrecht, the Netherlands.

Norman, H. D., R. H. Miller, and T. A. Cooper. 2010. Somatic cell counts of milk from Dairy Herd Improvement herds during 2009. USDA AIPL Report SCC11.

O'Reilly, K. M., M. J. Green, E. J. Peeler, J. L. Fitzpatrick, and L. E. Green. 2006. Investigation of risk factors for clinical mastitis in British dairy herds with bulk milk somatic cell counts less than 150,000 cells/ml. Vet. Rec. 158:649-653.

Olde Riekerink, R. G., H. W. Barkema, D. F. Kelton, and D. T. Scholl. 2008. Incidence rate of clinical mastitis on Canadian dairy farms. J. Dairy Sci. 91:1366-1377.

Olde Riekerink, R. G. M., I. Ohnstad, B. Van Santen, and H. W. Barkema. 2012. Effect of an automated dipping and backflushing system on somatic cell counts. J. Dairy Sci. 95:4931-4938.

Passchyn, P., S. Piepers, and S. De Vliegher. 2014. Pathogen groupspecific risk factors for intramammary infection in treated and untreated dairy heifers participating in a prepartum antimicrobial treatment trial. J. Dairy Sci. 97:6260-6270.

Peeler, E. J., M. J. Green, J. L. Fitzpatrick, K. L. Morgan, and L. E. Green. 2000. Risk factors associated with clinical mastitis in low somatic cell count British dairy herds. J. Dairy Sci. 83:2464-2472.

Piccand, V., E. Cutullic, S. Meier, F. Schori, P. L. Kunz, J. R. Roche, and P. Thomet. 2013. Production and reproduction of Fleckvieh, Brown Swiss, and 2 strains of Holstein-Friesian cows in a pasturebased, seasonal-calving dairy system. J. Dairy Sci. 96:5352-5363.

Prendiville, R., K. M. Pierce, and F. Buckley. 2010. A comparison between Holstein-Friesian and Jersey dairy cows and their F1 cross with regard to milk yield, somatic cell score, mastitis, and milking characteristics under grazing conditions. J. Dairy Sci. 93:27412750 .

Richert, R. M., K. M. Cicconi, M. J. Gamroth, Y. H. Schukken, K. E. Stiglbauer, and P. L. Ruegg. 2013. Risk factors for clinical mastitis, ketosis, and pneumonia in dairy cattle on organic and small conventional farms in the United States. J. Dairy Sci. 96:4269-4285.

Santman-Berends, I. M., T. J. Lam, J. Keurentjes, and G. van Schaik. 2015. An estimation of the clinical mastitis incidence per 100 cows per year based on routinely collected herd data. J. Dairy Sci. 98:6965-6977.
Sato, K., P. C. Bartlett, L. Alban, J. F. Agger, and H. Houe. 2008. Managerial and environmental determinants of clinical mastitis in Danish dairy herds. Acta Vet. Scand. http://dx.doi. org/10.1186/1751-0147-50-4.

Scherpenzeel, C. G., I. E. Den Uijl, G. Van Schaik, R. G. Olde Riekerink, J. M. Keurentjes, and T. J. Lam. 2014. Evaluation of the use of dry cow antibiotics in low somatic cell count cows. J. Dairy Sci. 97:3606-3614.

Schukken, Y. H., F. J. Grommers, D. van de Geer, H. N. Erb, and A. Brand. 1990. Risk factors for clinical mastitis in herds with a low bulk milk somatic cell count. 1. Data and risk factors for all cases. J. Dairy Sci. 73:3463-3471.

Scott, L. C., and P. I. Menzies. 2011. Antimicrobial resistance and small ruminant veterinary practice. Vet. Clin. North Am. Food Anim. Pract. 27:23-32.

SDa. 2014. The SDa report. The usage of antibiotics in livestock in 2013; trends and benchmark of herds and veterinarians (in Dutch). Accessed Jul. 20, 2015. http://www.autoriteitdiergeneesmiddelen. $\mathrm{nl} / \mathrm{nl} /$ publicaties.

SDa. 2015. The SDa report. The usage of antibiotics in livestock in 2014; trends and benchmark of herds and veterinarians (in Dutch). Accessed Nov. 8, 2015. http://www.autoriteitdiergeneesmiddelen. $\mathrm{nl} / \mathrm{nl} /$ publicaties.

Sérieys, F., Y. Raguet, L. Goby, H. Schmidt, and G. Friton. 2005. Comparative efficacy of local and systemic antibiotic treatment in lactating cows with clinical mastitis. J. Dairy Sci. 88:93-99.

StataCorp. 2014. Stata Software version 13. Stata Corporation, College Station, TX.

Swinkels, J. M., A. Hilkens, V. Zoche-Golob, V. Krömker, M. Buddiger, J. Jansen, and T. J. Lam. 2015. Social influences on the duration of antibiotic treatment of clinical mastitis in dairy cows. J. Dairy Sci. 98:2369-2380.

Swinkels, J. M., V. Krömker, and T. J. Lam. 2014. Efficacy of standard vs. extended intramammary cefquinome treatment of clinical mastitis in cows with persistent high somatic cell counts. J. Dairy Res. 81:424-433.

van den Borne, B. H. P., G. Van Schaik, T. J. G. M. Lam, and M. Nielen. 2010. Variation in herd level mastitis indicators between primiand multiparae in Dutch dairy herds. Prev. Vet. Med. 96:49-55.

van den Borne, B. H. P., J. C. M. Vernooij, A. M. Lupindu, G. Van Schaik, K. Frankena, T. J. G. M. Lam, and M. Nielen. 2011. Relationship between somatic cell count status and subsequent clinical mastitis in Dutch dairy cows. Prev. Vet. Med. 102:265-273.

Vance, E. R., C. P. Ferris, C. T. Elliot, S. A. McGettrick, and D. J. Kilpatrick. 2012. Food intake, milk production, and tissue changes of Holstein-Friesian and Jersey $\times$ Holstein-Frisian dairy cows within a medium-input grazing system and a high-input total confinement system. J. Dairy Sci. 95:1527-1544.

Walsh, S., F. Buckley, D. P. Berry, M. Rath, K. Pierce, N. Byrne, and P. Dillon. 2007. Effects of breed, feeding system, and parity on udder health and milking characteristics. J. Dairy Sci. 90:5767-5779. 